\title{
The Relationship between Branchiosomatic and Pulmosomatic Indices in the African Lungfish, Protopterus Annectens of Anambra River, Nigeria
}

\author{
Anthony I. Okafor \\ Department of Animal and Environmental Biology \\ Abia State University, Uturu-Nigeria \\ E-mail: tconnection68@yahoo.com
}

Received: November 22, 2012 Accepted: December 6, 2013

doi:10.5296/jbls.v5i1.5213 URL: http://dx.doi.org/10.5296/jbls.v5i1.5213

\begin{abstract}
The relationship between Branchiosomatic indices (BSI) and Pulmosomatic indices (PSI) in various sizes of the African lungfish, Protopterus annectens procured from Anambra River was determined. There was an inverse relationship between BSI and PSI. Mean BSI exhibited highest values of between 0.90 and 0.96 in the fingerlings, then began to decrease as the fish grew until it reached minimum values of between 0.36 and 0.44 in the large sized P. annectens. Conversely, mean PSI showed minimum values of between 0.32 and 0.48 in the fingerlings, then rose to a peak of between 0.88 and 1.06 in the large sized $P$. annectens. The study tends to support the palaeontological evidence which states that the Amphibians evolved from some now extinct fish groups related to the lungfishes during the Devonian period.
\end{abstract}

Keywords: Branchiosomatic, Pulmosomatic, Inverse relationship, Devonian period.

\section{Introduction}

The African lungfish, Protopterus is amphibious using its gills to absorb oxygen whilst immersed in water and its lungs for absorption of atmospheric oxygen.(Okafor,2012)

It inhabits shallow and swampy parts of some Rivers and Lakes of some African countries during the wet season (Giusi et al, 2011; Icardo et al, 2011,2012; Laberge and Walsh, 2011;) However, during the dry season, when the ambient water has totally dried up, Protopterus excavates a burrow in the soil where it resides in a dormant state until the end of the season. (Okafor et al 2011; Loong et al, 2012 a,b). 


\section{Macrothink}

The life history of $P$. annectens of West Africa has been detailed by Johnels and Svensson (1954). The eggs hatch in water and parental care includes stirring or agitation of the water by the male. (Johnels and Svensson, 1954; Icardo et al, 2012). This water stirring is necessary in order to ensure that oxygen gets into the developing eggs as well as the newly hatched fry. It has been observed that young, $P$. annectens starts to gulp in air at the water surface at a mean length of between 2.5 and $3.0 \mathrm{~cm}$, even prior to the beginning of active feeding which usually does not begin until the yolk sac is consumed at the mean length of $5.5 \mathrm{~cm}$ (Smith, 1931; Johnels and Svensson, 1954; Aniamalu, 2012; Icardo et al, 2012).

There have been little or no studies, however, on the relative weights of the gills and lungs of various sizes or developmental stages of $P$. annectens. The present study therefore aims to fill this gap in knowledge by seeking to define more precisely the relationship between the gill weight and lung weight in various sizes of the African lungfish P. annectens of Anambra River, Nigeria.

\section{Materials and Methods}

\subsection{Procurement of Varied Sizes of the Lungfish}

A total of 364 live specimens of the African lungfish, $P$. annectens comprising 81 fingerlings (mean length $23.6 \pm 7.2 \mathrm{~cm}$; mean weight $48.7 \pm 9.3 \mathrm{~g}$ ) 94 juveniles (mean length, $30.2 \pm 5.8 \mathrm{~cm}$, mean weight $206.3 \pm 17.5 \mathrm{~g}$ ) 138 intermediates (mean length, $37.1 \pm 6.4 \mathrm{~cm}$; mean weight , $358.5 \pm 14.2 \mathrm{~g}$ ) and 51 large (mean length $50.6 \pm 9.5 \mathrm{~cm}$; mean weight $1061.2 \pm 82.3 \mathrm{~g}$ ) specimens were used for the study.

They were procured from three sampling stations of Anambra River (Latitude $5^{0} 42^{\prime} \& 7^{0} 40^{\prime}$ North, and Longitude $6^{0} 30^{\prime} \& 7^{0} 42^{\prime}$ East) namely: Ogurugu, Otuocha and Nsugbe, all within Anambra and Enugu States of Nigeria (Fig. 1). 


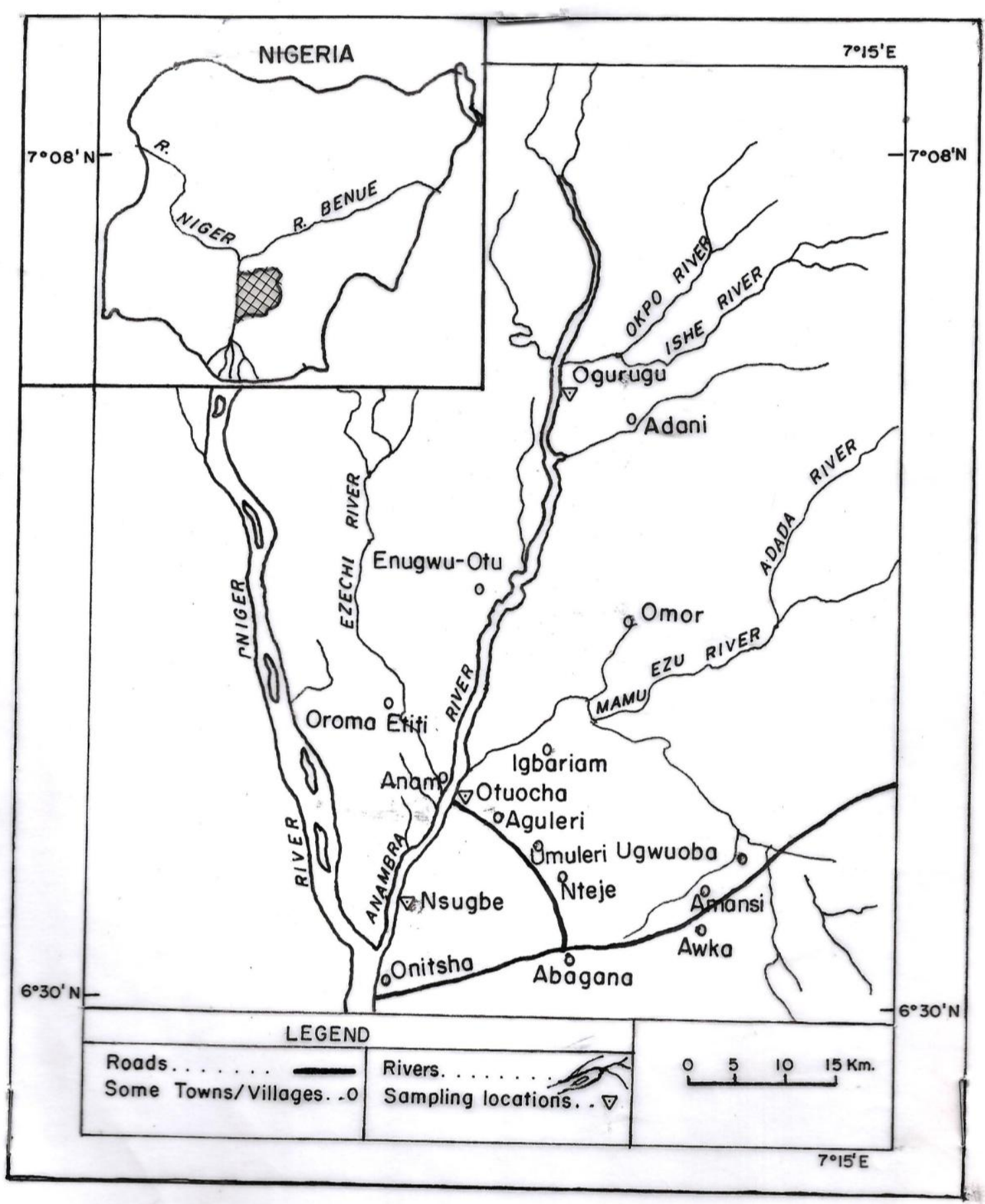

Fig. 1. Map of Anambra River in Nigeria, showing Ogurugu, Otuocha and Nsugbe sampling stations

At Ogurugu, 25 fingerlings, 37 juveniles, 52 intermediates and 24 large $P$. annectens were procured. At Otuocha, 36 fingerlings, 29 juveniles, 61 intermediates and 11 large specimens were obtained, while at Nsugbe station, the samples were 20 fingerlings, 28 juveniles, 25 intermediates and 16 large specimens. 


\subsection{Determination of Branchiosomatic and Pulmosomatic Indices}

All specimens were transported to Animal and Environmental Biology laboratory of Abia State University, Uturu where the standard length and weights of all live ones were quickly determined. Each live specimen was then immediately dissected to bring out its gills and lungs, whose respective weights were also quickly determined.

The weight of the gills in relation to body weight or Branchiosomatic index (BSI) of each specimen was calculated as:

$$
\text { BSI }=\frac{\text { weight of gills } \times 100}{\text { Body weight }}
$$

Similarly, the weight of the lungs in relation to body weight or Pulmosomatic index (PSI) of each specimen was calculated as:

$$
\text { PSI }=\frac{\text { Weight of lungs } x 100}{\text { Body weight }}
$$

The mean BSI and PSI within a particular range of standard length of P. annectens as well as the mean body weights within that same range of standard length were determined.

\subsection{Statistical Analysis.}

The arithmetic means and standard deviations of the standard length and weights of all specimens (fingerlings, juveniles, intermediates, large) procured from each of the three sampling stations were determined.

Bar graphs were used to represent the mean Branchiosomatic and Pulmosomatic indices of various sizes of $P$. annectens procured from each station of Anambra River.

\section{Results}

The mean BSI and PSI within various ranges of standard length of $P$. annectens as well as the mean body weights within those ranges are presented in Tables 1, 2, and 3 corresponding to specimens procured from Ogurugu, Otuocha and Nsugbe sampling stations respectively of Anambra River.

Table 1. Branchiosomatic and Pulmosomatic indices of Protopterus annectens procured from Ogurugu sampling station of Anambra River

\begin{tabular}{|c|c|c|c|c|}
\hline Size & Range of standard length $(\mathrm{cm})$ & Mean body weight $(\mathrm{g})$ & Mean BSI & Mean PSI \\
\hline \multirow{2}{*}{ Fingerlings } & $14.1-22.0$ & 41.1 & 0.96 & 0.32 \\
& $22.1-28.0$ & 66.2 & 0.82 & 0.65 \\
\hline \multirow{2}{*}{ Juveniles } & $28.1-30.0$ & 198.9 & 0.76 & 0.71 \\
& $30.1-33.0$ & 216.8 & 0.66 & 0.74 \\
\hline \multirow{2}{*}{ Intermediates } & $33.1-37.0$ & 307.3 & 0.55 & 0.80 \\
& $37.1-44.0$ & 362.8 & 0.48 & 0.78 \\
\hline \multirow{2}{*}{ Large } & $44.1-48.0$ & 474.8 & 0.37 & 0.91 \\
& $48.1-60.0$ & 1216.5 & 0.36 & 1.06 \\
\hline
\end{tabular}




\section{Macrothink}

Journal of Biology and Life Science ISSN 2157-6076 2014, Vol. 5, No. 1

Table 2. Branchiosomatic and Pulmosomatic indices of Protopterus annectens procured from Otuocha sampling station of Anambra River.

\begin{tabular}{|c|c|c|c|c|}
\hline Size & Range of standard length $(\mathrm{cm})$ & Mean body weight $(\mathrm{g})$ & Mean BSI & Mean PSI \\
\hline \multirow{2}{*}{ Fingerlings } & $14.1-22.0$ & 41.9 & 0.95 & 0.41 \\
& $22.1-28.0$ & 64.3 & 0.91 & 0.48 \\
\hline \multirow{2}{*}{ Juveniles } & $28.1-30.0$ & 183.6 & 0.87 & 0.70 \\
& $30.1-33.0$ & 224.6 & 0.84 & 0.70 \\
\hline \multirow{2}{*}{ Intermediates } & $33.1-37.0$ & 318.9 & 0.63 & 0.79 \\
& $37.1-44.0$ & 377.5 & 0.52 & 0.81 \\
\hline \multirow{2}{*}{ Large } & $44.1-48.0$ & 482.6 & 0.47 & 0.86 \\
& $48.1-60.0$ & 1115.4 & 0.39 & 0.88 \\
\hline
\end{tabular}

Table 3. Branchiosomatic and Pulmosomatic indices of Protopterus annectens procured from Nsugbe sampling station of Anambra River.

\begin{tabular}{|c|c|c|c|c|}
\hline Size & Range of standard length $(\mathrm{cm})$ & Mean body weight $(\mathrm{g})$ & Mean BSI & Mean PSI \\
\hline \multirow{2}{*}{ Fingerlings } & $14.1-22.0$ & 46.4 & 0.90 & 0.48 \\
& $22.1-28.0$ & 60.6 & 0.90 & 0.54 \\
\hline \multirow{2}{*}{ Juveniles } & $28.1-30.0$ & 209.9 & 0.81 & 0.72 \\
& $30.1-33.0$ & 237.4 & 0.64 & 0.74 \\
\hline \multirow{2}{*}{ Intermediates } & $33.1-37.0$ & 313.5 & 0.64 & 0.79 \\
& $37.1-44.0$ & 388.8 & 0.49 & 0.85 \\
\hline \multirow{2}{*}{ Large } & $44.1-48.0$ & 430.1 & 0.45 & 0.89 \\
& $48.1-60.0$ & 1008.5 & 0.44 & 0.89 \\
\hline
\end{tabular}

The mean weights of the gills and lungs of $P$. annectens in relation to their mean body weights are shown in Figs 2, to 7

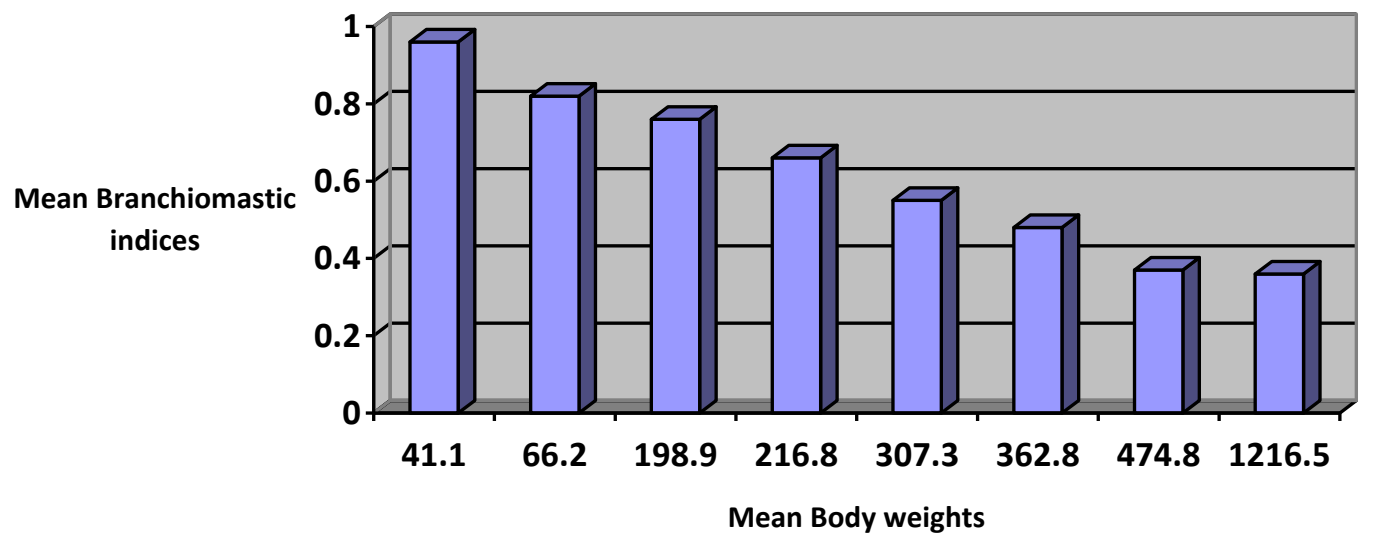

Fig 2. The mean weights of the gills in relation to mean body weights of Protopterus annectens procured from Ogurugu sampling station of Anambra River. 


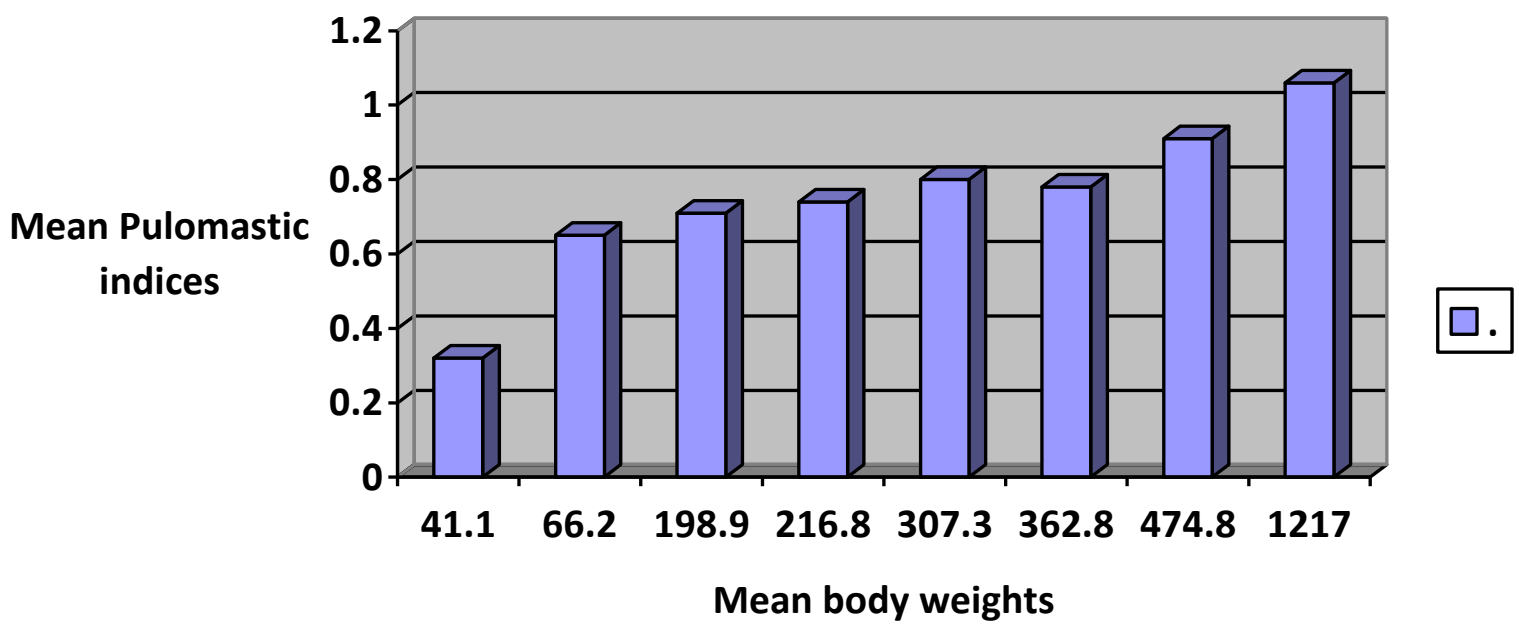

Fig 3. The mean weights of the lungs in relation to mean body weights of Protopterus. annectens procured from Ogurugu sampling station of Anambra River.

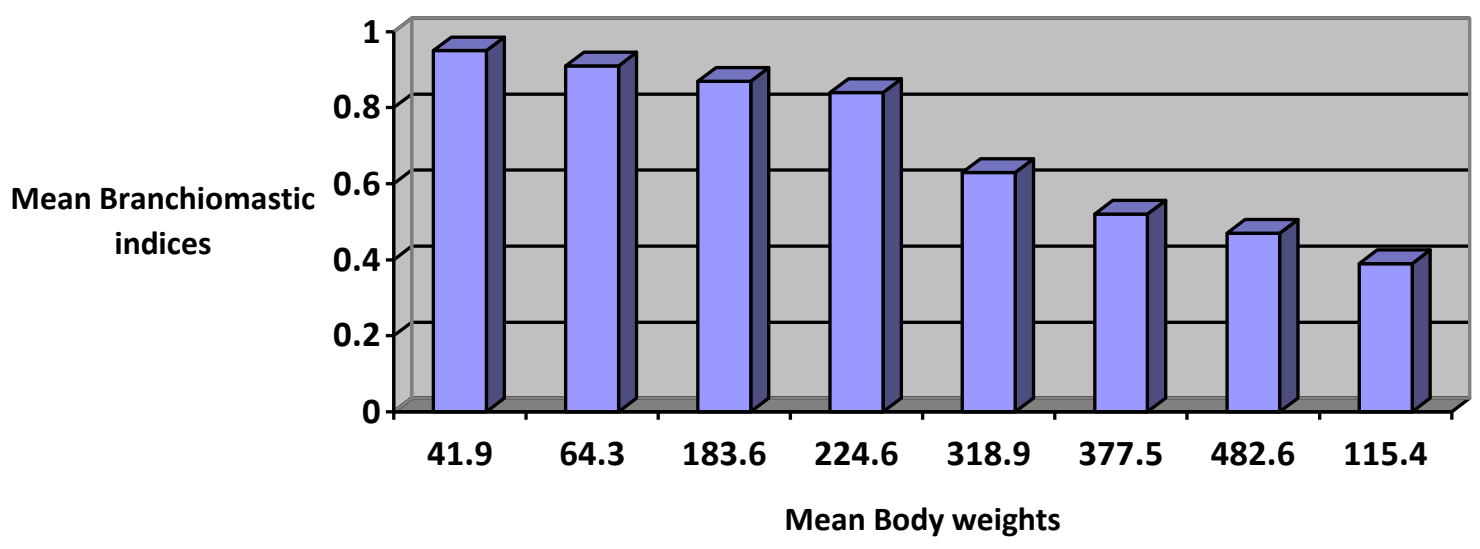

Fig 4. The mean weights of the gills in relation to mean body weights of Protopterus annectens procured from Otuocha sampling station of Anambra River. 


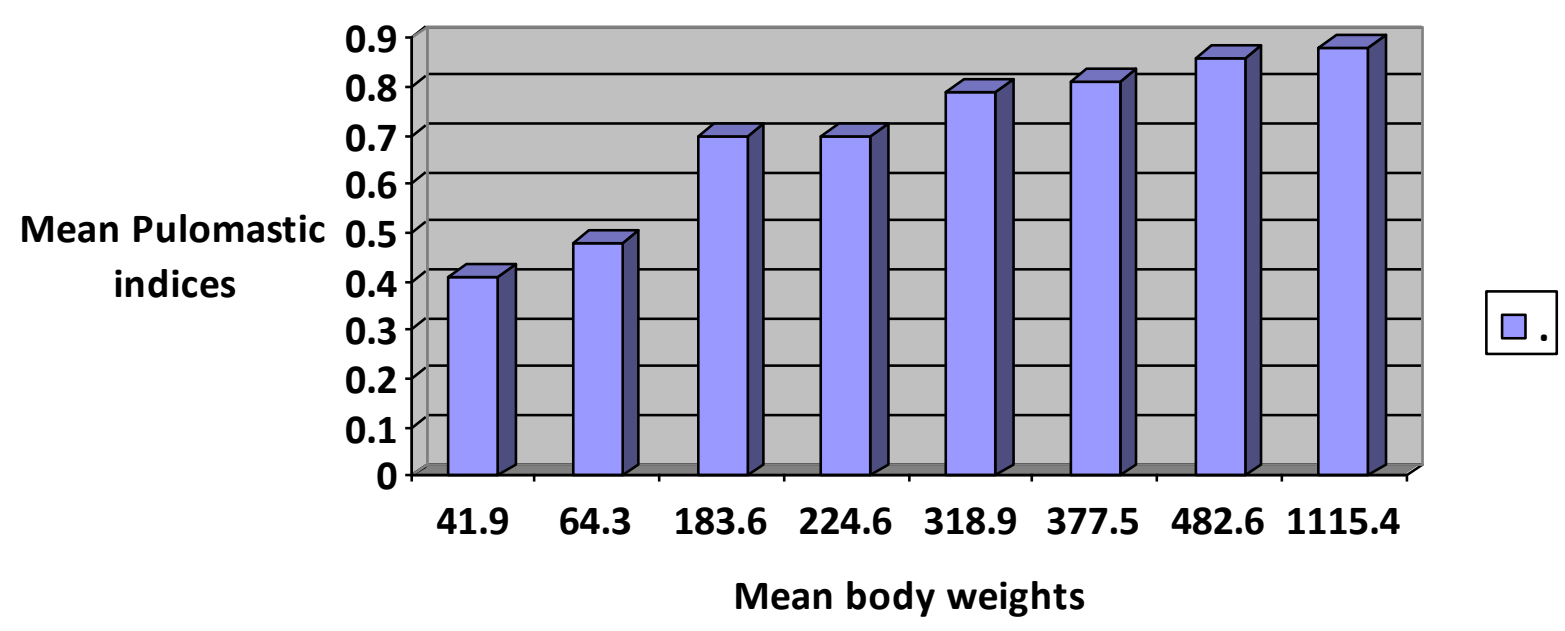

Fig 5. The mean weights of the lungs in relation to mean body weights of Protopterus annectens procured from Otuocha sampling station of Anambra River.

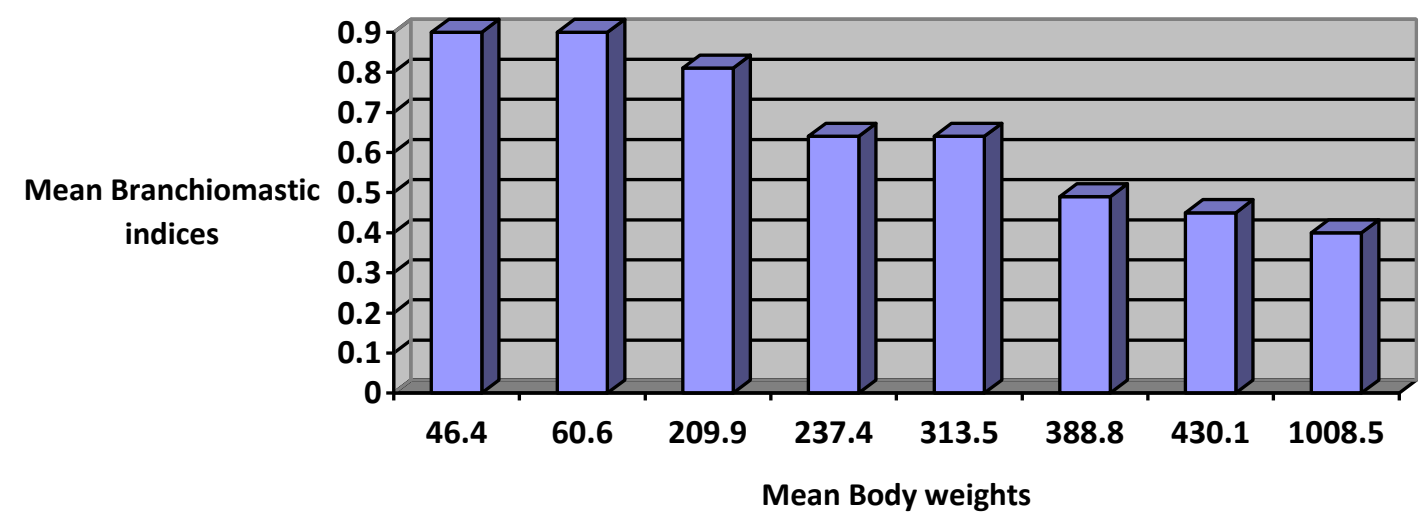

Fig 6. The mean weights of the gills in relation to mean body weights of Protopterus. annectens procured from Nsugbe sampling station of Anambra River. 


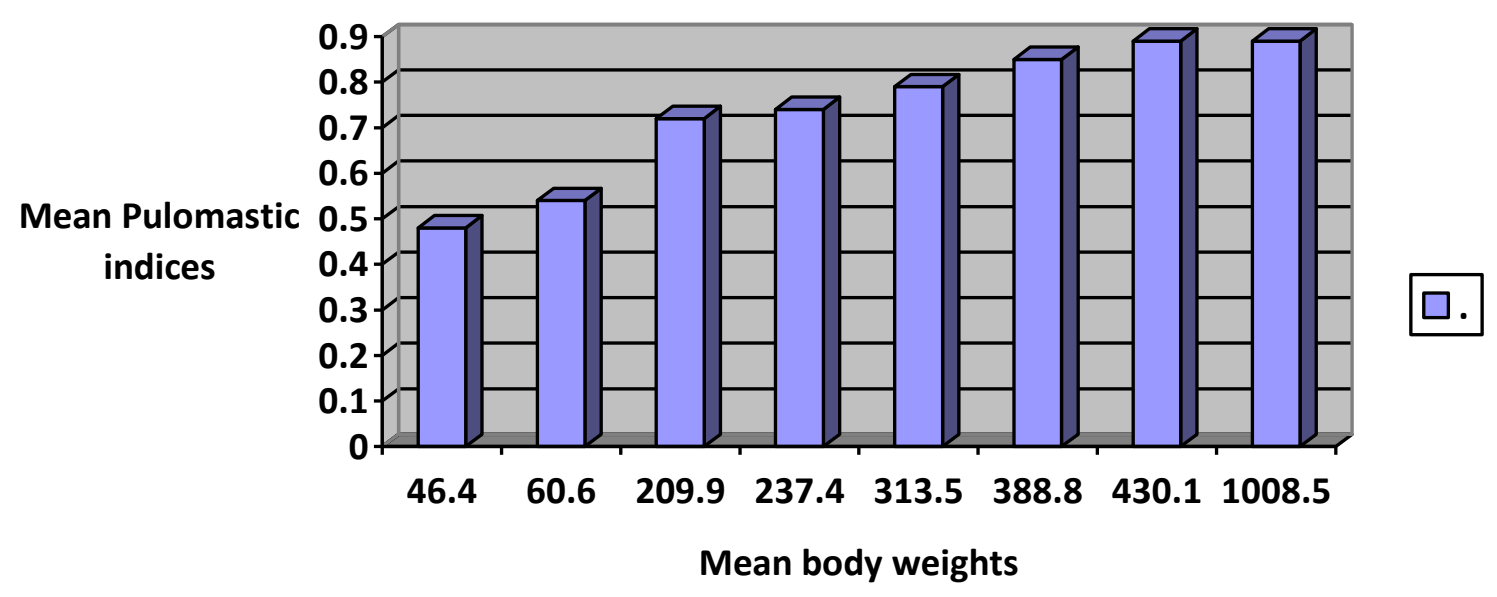

Fig 7. The mean weights of the lungs in relation to mean body weights of Protopterus annectens procured from Nsugbe sampling station of Anambra River.

also corresponding to specimens collected from Ogurugu,. Otuocha and Nsugbe sampling stations of Anambra River respectively.

\section{Discussion}

The study clearly shows an inverse relationship between mean BSI and mean PSI (Figs 2 to 7). If the fingerling stage of the specimens obtained from Ogurugu station was taken as a reference, mean BSI was as high as 0.96 while mean PSI was as low as 0.32 . However, as the lungfish was growing and getting larger in size, mean BSI was declining while mean PSI was rising (Figs. 2-3). This could be attributed to the fact that as the fish, P. annectens grew from fingerling to juvenile stage upwards, it was relying more on aerial respiration via the lungs and less on aquatic respiration via the gills. In other words, the lungs were gradually becoming developed, while the gills were continuously degenerating, and this trend continued until the adult stage was fully attained.

The work partly agrees with that of Lenfant and Johansen (1968) who reported that adult East African lungfish, $P$. aethiopicus relied on aerial respiration occurring via the lungs for $90 \%$ of its oxygen requirements. Similarly, it had earlier been reported that adult South American lungfish, Lepidosiren paradoxa relied on lung respiration for $96 \%$ of its oxygen requirements (Sawaya, 1946). But in the juvenile Lepidosiren paradoxa, Johansen and Lenfant (1967) reported that aquatic oxygen uptake via the gills was higher than that of aerial oxygen uptake via the lungs. In the Australian lungfish, Neoceratodus forsteri, all oxygen uptake while at rest are obtained in the aquatic exchange via the gills. (Lenfant et al, 1966; Joss, 2011) The single or unpaired lung in $N$. forsteri just serves as an accessory respiratory organ during increased physical stress or in highly polluted waters that kill other fishes (Grigg, 1965; Joss, 2011; Lopez et al, 2012).

This study, as well as palaeontological studies, tend to support the view that the amphibians evolved from some fish groups related to the lungfishes during the Devonian period.(Carroll, 
1997; King et al, 2011). The amphibians have two stages in their life history. The tadpoles live in water and possess several fish-like features including well developed gills, but with primitively developed lungs. As the tadpole grows, the lungs progressively become more developed whereas the gills continue to degenerate. (Young, 1973) Then just before the young amphibian leaves its aquatic life to begin a terrestrial type of life, the lungs have become fully developed while the gills have completely degenerated . (Young, 1973).

The reason for lung development may be found through a consideration of probable Devonian climatic conditions. The Devonian period or the Age of Fishes was a time of violent alternation of seasons (Caroll, 1997; Ahlberg et al, 2003; King et al, 2011; Shan and Gras, 2011). There were wet seasons alternating with times of severe drought (Randall et al, 1981; Carroll, 1997). As the streams and ponds where the Devonian fishes were living were drying up rapidly, the only way of surviving while crawling from a dried up pond into another that still had water in it was to evolve air breathing organs for aerial respiration. Some of such organs were the lungs, swim bladder, stomach, intestine, epibranchial organs, skin etc (Randall et al 1981; Lagler 1986; Carroll, 1997). Some evolved leg-like fins which they could use to crawl from one drying out pond into another that still had water in it. Thus, at this period, before the splitting of Pangaea, an extinct Crossopterygian group related to modern lungfish evolved into amphibians and eventually all tetrapods (Randall et al, 1981; Brinkmann et al, 2004; Shan and Gras, 2011). This helps to explain the homology between many organs of lungfish with those of amphibians, indicating a closer relationship between these two groups than can be revealed by palaeontological or other physiological or genetic studies (King et al, 2011; Shan and Gras,2011).

This work also partly agrees with that of Okafor (2008) who reported that as the African lungfish, Protopterus grew in size, it became less ammonotelic but more ureotelic, uricotelic and even creatininotelic respectively.

As has already been mentioned, the amphibian tadpole recapitulates this practice of the gills degenerating as the lungs are developing during its ontogeny. (Young, 1973). This therefore implies that the amphibians evolved from either the lungfish or a fish group related to the lungfish during the Devonian period (Randall et al, 1981; Little, 1990; Carroll, 1997).

This paper thus highlights the relative importance of changes in gills and lung weights in various sizes or developmental stages of the African lungfish, P. annectens.

\section{Acknowledgement}

The author is grateful to the fishermen at Ogurugu,Otuocha and Nsugbe stations of River Anambra for their cooperation in providing him with variety of sizes of the lungfish.

\section{References}

Ahlberg, P. E, Johansen, Z., Zerina, J., \& Daeschler, E. B. (2003). The Late Devonian Lungfish, Soederberghia ( Sarcopterygii, Dipnoi) from Australia and North America and its biogeographical implications. Journal of Vertebrate Palaeontology 21(1), 1-12. http://dx.doi.org/10.1671/0272-4634(2001)021[0001:TLDLSS]2.0.CO;2 
Aniamalu, D.O (2012). Parental care by the male African lungfish, Protopterus annectens. B.Sc thesis. Abia State University Uturu-Nigeria

Brinkmann, H., Venkatesh, B., Brenner, S, \& Meyer, A. (2004). Nuclear protein coding genes support lungfish and not Coelacanth as the closest living relative of land vertebrates. Proc. Nat. Acad. Sci . U.S.A. 101, 4900-4905. http://dx.doi.org/10.1073/pnas.0400609101

Carroll, R. L. (1997). Patterns and processes of Vertebrate evolution. Cambridge Palaebiology series. Cambridge University Press, Cambridge.

Giusi G., Crudo, M., Di Vito, A., Facciolo, R. M., Garofalo, F., Chew, S. F., I p, Y. K., \& Canonaco, M., (2011). Lungfish aestivating activities are locked in distinct encephalic $\gamma$-aminobutyric acid type A receptor $\propto$ subunits. Journal of Neuro Science 89(3), 418-428.

Grigg, C. (1965). Studies of the Queensland lungfish, Neoceratodus forsteri (Krefft) III. Aerial respiration in relation to habits. Aust.J. Zool. 13, 413- 421. http://dx.doi.org/10.1071/ZO9650413

Icardo, J. M., Loong, A. M, Colvee, E., Wong, W. P., \& Ip, Y. K. (2012). The alimentary canal of the African lungfish, Protopterus annectens during aestivation and after arousal. Anat. Rec. Hoboken 295(1), 60-72. http://dx.doi.org/10.1002/ar.21476

Icardo, J. M., Wong, W. P., Colvee, E., Garofalo, F., Loong, A. M., \& Ip, Y. K., (2011). The gut of the juvenile African lungfish, Protopterus annectens: a light and scanning electron $\begin{array}{lllll}\text { microscope study. Journal of } & \text { Morphology } & \text { 2779). }\end{array}$ http://dx.doi.org/10.1002/jmor.10952

Johansen, K \& Lenfant, C (1967) Respiratory function in theSouth American lungfish, Lepidosiren paradoxa. Journal of Experimental; Biology 46, 205-218.

Johnels, A. G, \& Svensson, G. S. O. (1954). On the biology of Protopterus annectens Ark. Zool. 7, 131-164.

Joss, J. M. (2011). The Australian lungfish, Neoceratodus forsteri: as personal story. General Comparative Endocrinology, 173(1), 1-3. http://dx.doi.org/10.1016/j.ygcen.2011.05.004

King, H. M., Shubin, N. H., Coates, M. I., \& Hale, M. E., (2011). Behavioral evidence for the evolution of walking and bounding before terrestriality in Sarcopterygian fishes. Proc. Natl. Acad. Sci U.S.A. 108(52), 21146-51. http://dx.doi.org/10.1073/pnas.1118669109

Laberge, T, \& Walsh, P. J. (2011). Phylogenetic aspects of carbamoyl phosphate synthetase in lungfish: a transitional enzyme in transitional fishes. Comp. Biochem. Physiol. Part D. Genomics Proteomics, 6(2), 187-194. http://dx.doi.org/10.1016/j.cbd.2011.03.001

Lagler, K. F (1986). Ichthyology. John Wiley and Sons, London. P. 545.

Lenfant, C, \& Johansen, K. (1968). Respiration in the African lungfish, Protopterus aethiopicus.I Respiratory properties of blood and normal patterns of breathing and gas exchange. J. Expt. Biol. 49, 437-452. 
Lenfant, C., Johansen, K, \& Grigg, C. C, (1966) Respiratory properties of blood and pattern of gas exchange in the lungfish, Neoceratodus forsteri (Krefft). Respir. Physiol., 2, 1-21. http://dx.doi.org/10.1016/0034-5687(66)90034-X

Little, C. (1990). The terrestrial invasion: An ecophysiological approach to the origins of land animals. Cambridge University Press, Cambridge.

Loong, A. M., Chng, Y. R., Chew, S. F., Wong, W. P., \& Ip, Y. K. (2012 b) Molecular characterization and mRNA expression of carbamoyl phosphate synthetase III in the liver of the African lungfish, Protopterus annectens during aestivation or exposure to ammonia. $J$. Comp Physiol. B 182(3), 367-79. http://dx.doi.org/10.1007/s00360-011-0626-7

Loong, A. M., Hiong, K. C., Wong, W. P., Chew, S. F., \& Ip, Y. K. (2012 a) Differential gene expression in the liver of the African lungfish, Protopterus annectens after 6 days of aestivation in air. J. Comp. Physiol. B 182(2), 231-45. http://dx.doi.org/10.1007/s00360-011-0613-z

Lopez, J. M., Dominguez, L., Morona, R., Northcutt, R. G, \&Gonzalez, A. (2012). Organization of the cholinergic systems in the brain of two lungfishes, Protopterus dolloi and Neoceratodus forsteri. Brain Struct. Funct 217(2), 549-76. http://dx.doi.org/10.1007/s00429-011-0341-x

Okafor, A. I, (2008). Ammonia production rate and quantitative determination of nitrogenous wastes in various sizes of the African lungfish, Protopterus annectens (O). J. Sci Engr. Tech 15(1), 8183-8190.

Okafor, A. I. (2012). Urea accumulation in acid water by the African lungfish, Protopterus annectens (Owen) of Oguta Lake, Nigeria. Asian Journal of Microbiology, Biotechnology and Environmental Sciences, 14(1), 7-12.

Okafor,A. I; Nwani, C. D, \& Okereke, F. O. (2011) Utilization of lipids during aestivation of the African lungfish, Protopterus annectens. J. Environ. Biol 32, 31-34.

Randall, D. J., Burggren, W. W., Farell, A. P, \& Haswell, M. S. (1981). The evolution of air-breathing Vertebrates. Cambridge University Press, Cambridge.

Sawaya P. (1946)Sobre a bologia de alguns peixes de respiracao aerea (L. paradoxa (Fitz) e Arapaima gigas Cuvier) Bolm. Fac. Filos. Cienc Letr Univ S. Paulo II; 255-286.

Shan, Y., \& Gras, R. (2011). 43 genes support the lungfish-coelacanth grouping related to the closest living relative of tetrapods with the Bayesian method under the coalescence model. BMC Res. Notes 4; 49. http://dx.doi.org/10.1186/1756-0500-4-49

Smith, H. W. (1931). Observations on the African lungfish, Protoptesrus aethiopicus and the evolution from water to land environments. Ecology 12. 164-181. http://dx.doi.org/10.2307/1932938

Young, J. Z. (1973). The Life of Vertebrates. Oxford University Press, London. 


\section{Copyright Disclaimer}

Copyright reserved by the author(s).

This article is an open-access article distributed under the terms and conditions of the Creative Commons Attribution license (http://creativecommons.org/licenses/by/3.0/). 